\title{
Graveoline from Ruta angustifolia (L.) Pers. and Its Antimicrobial Synergistic Potential in Erythromycin or Vancomycin Combinations \\ (Graveolin daripada Ruta angustifolia (L.) Pers. dan Potensi Sinergistik Antimikrobnya dalam Gabungan Erithromicin atau Vancomicin)
}

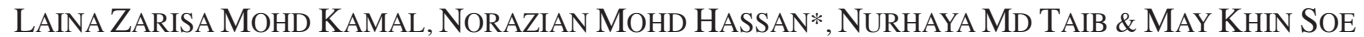

\begin{abstract}
Ruta angustifolia (L.) Pers. is a Rutaceous species which contains various anthranilic acid derived alkaloids including the bioactive quinolones. This study is aimed at identifying the antimicrobial active alkaloids of R. angustifolia and evaluating their potential as synergistic enhancers in alkaloid-antibiotic combinations. Antimicrobial bioautographyguided isolation of alkaloidal fractions of $\mathrm{R}$. angustifolia leaves has led to the identification of 2,3-dimethoxy-1-hydroxy10-methylacridone [arborinine]; and 4,7,8-trimethoxyfuro[2,3-b]quinoline [skimmianine]; together with the major active alkaloid, 1-methyl-2-[3',4'-methylenedioxyphenyl]-4-quinolone [graveoline]. Graveoline showed Minimum Inhibitory Concentration (MIC) values ranging from 500 to $1000 \mu \mathrm{g} / \mathrm{mL}$ against Staphylococcus aureus ATCC 25923, Enterococcus faecalis ATCC 29212 and Escherichia coli ATCC 25922. Checkerboard assay for antimicrobial combination effects between graveoline with either erythromycin or vancomycin showed enhancement of the antimicrobial activity of both antibiotics with Fractional Inhibitory Concentration Indices (FICI) ranged from 0.37 to 1.50. Synergistic effect with FICI of 0.37 was observed for graveoline-erythromycin combination against $\mathrm{S}$. aureus compared to FICI of 1.00 for ciprofloxacin-erythromycin additive effect. Graveoline was a potential candidate for antimicrobial combination agent especially against $\mathrm{S}$. aureus. The result supports the idea of using plant metabolites as antimicrobial synergistic agents.
\end{abstract}

Keywords: Antimicrobial; graveoline; Ruta angustifolia; synergistic enhancer

\section{ABSTRAK}

Ruta angustifolia (L.) Pers. adalah spesies Rutaceae yang mengandungi pelbagai alkaloid yang hasilkan daripada asid anthranilik seperti alkaloid quinolon. Kajian ini bertujuan untuk mengenal pasti alkaloid aktif daripada $\mathrm{R}$. angustifolia dan potensinya sebagai penggalak kesan sinergi bersama antibiotik terpilih. Pemencilan alkaloid aktif berpandukan bioautografi antimikrob daripada pecahan ekstrak daun R. angustifolia berjaya mengenal pasti 2,3-dimetoksi-1hidroksi-10-metilakridon [arborinin]; dan 4,7,8-trimetoksifuro[2,3-b]quinolin [skimmianin]; dan akaloid aktif utama 1-metil-2-[3',4'-metilenedioksifenil]-4-quinolon [graveolin]. Graveolin menunjukkan Kepekatan Perencatan Minima (MIC) pada julat antara 500 dan $1000 \mu \mathrm{g} / \mathrm{mL}$ terhadap Staphylococcus aureus ATCC 25923, Enterococcus faecalis ATCC 29212 dan Escherichia coli ATCC 25922. Gabungan antara graveolin dan erithromicin atau vankomicin yang dinilai melalui Assay Checkerboard menunjukkan bahawa graveolin meningkatkan aktiviti kedua-dua antibiotik dengan Indeks Pecahan Kepekatan Perencatan (FICI) antara 0.37 dan 1.50. Kesan sinergi dengan nilai FICI 0.37 ditunjukkan oleh gabungan graveolin-erithromicin terhadap S. aureus berbanding kesan tambahan dengan nilai FICI 1.00 oleh gabungan ciprofloxacin-erithromicin. Graveolin mempunyai potensi sebagai agen gabungan antimikrob terutama terhadap S. aureus. Keputusan kajian ini menyokong penggunaan metabolit daripada tumbuhan sebagai agen sinergi antimikrob.

Kata kunci: Antimikrob; graveolin; penggalak sinergistik; Ruta angustifolia

\section{INTRODUCTION}

The resistance in current antibiotics which restricts their effectiveness in the standard treatment of infections has dramatically increasing due to global emergence of multi-drug resistant bacterial strains. The global concern on the present updates on widespread antibiotic resistance include treatment failure of Escherichia coli, Klebsiella pneumoniae, Staphylococcus aureus and Enterobacteriaceae infections to fluroquinolones, carbapenem, the first line drugs treatment and colistin, respectively. Erythromycin, vancomycin and ciprofloxacin are among the antibiotics which are prone to be degraded by the bacterial enzymatic resistance mechanism (WHO 2017). One of the strategies employed in overcoming limited number of antimicrobial agents that are currently available in fighting the highly resistant strains is antibiotic combination therapy (Tamma et al. 2012).

Plant-based natural product is one of the ideal candidates in discovering new class of antimicrobial agent and has contributed in surviving the increasing number of bacterial resistance towards currently existing antibiotics (Abreu et al. 2012). These phytochemicals are potential 
antimicrobial combination agents since several compounds have also been found to be synergistic enhancers (Kyaw et al. 2012; Linda et al. 2011). Although they may possessed weak inhibitory activity alone but when combined with certain antibiotics they enhanced the activity of the later (Kyaw et al. 2012). The combination also has been recognised as important approach for delaying the emergence of bacterial resistance and may also eventually reduced the undesirable side effects of the antibiotics (Hemaiswarya \& Doble 2010).

Rutaceae has been a source of interest for its novel anthranillic acid derived alkaloids with biologically active antibacterial and antifungal properties (da Silva et al. 2013). Ruta angustifolia (Garuda or Aruda in Malay) of the Rutaceae is one of the rich sources of anthranilic acid derived alkaloids including acridone, quinoline, quinolone and furoquinoline alkaloids (El Sayed et al. 2003). It is a small shrub with strong and unpleasant smell and used traditionally for treating ear infection, boils and bruised (Shamsul et al. 2003). Alkaloids are among the bioactive phytochemicals which are responsible for the antimicrobial activity possessed by Ruta species (Raj et al.2013). The reported alkaloids of $R$. angustifolia include rutaverine, arborinine, fagarine, graveolinine, graveoline and skimmianine (Koh et al. 2009). The present study was undertaken to isolate and identify the antimicrobial active alkaloids of $R$. angustifolia, and evaluating their potential as synergistic enhancers in alkaloid-antibiotic combinations with either erythromycin or vancomycin.

\section{MATERIALS AND METHODS}

\section{INSTRUMENTATIONS}

Spots on TLC chromatograms were visualized under UV lights at 254 and $365 \mathrm{~nm}$ by using Fluorescent Analysis Cabinet (SPECTROLINE, CM-10). Alkaloid purification was performed using chromatotron (Model 7924T, Harrison Research U.S.A) with silica gel containing gypsum Kieselgel $60 \mathrm{PF}_{254}$ (Merck, 7749) as the stationary phase. Melting point was determined using digital melting point apparatus (Stuart's SMP20) equipped with microscope. Ultraviolet spectra were recorded in methanol using HITACHI, U-2900 Spectrophotometer. The infrared spectra were recorded on Perkin Elmer FTIR Spectrum 2000 Spectrometer with chloroform as solvent. ${ }^{1} \mathrm{H}$ NMR and ${ }^{13} \mathrm{C}$ NMR spectra were recorded on a Bruker, $500 \mathrm{MHz}$ (Avance III, Ultrashield Plus) Spectrometer. MS were recorded by direct probe method using Thermofinnigan Trace GC-Polaris-Q GCMS.

\section{PLANT MATERIALS}

Ruta angustifolia (L.) Pers. was purchased at Muar, Johor, Malaysia. The plant species was verified by Dr. Shamsul Khamis, the botanist of Herbarium, Universiti Kebangsaan Malaysia (UKMB). A voucher specimen (PIIUM 0002-1) was deposited at the Herbarium, Kulliyyah of Pharmacy, International Islamic University Malaysia.

\section{EXTRACTION}

The dried leaves (400 g) were defatted with hexane and then extracted with acetone $(4 \mathrm{~L})$ using soxhlet apparatus. The extract was concentrated to $1 / 8$ of its original volume and extracted exhaustively with $2 \%$ hydrochloric acid until Mayer's test became negative. The acidic aqueous solution was basified with $0.5 \mathrm{M}$ sodium hydroxide to $\mathrm{pH} 8-9$ and extracted with $\mathrm{CHCl}_{3}$ until extinction. The crude alkaloidal extract was then dried using sodium sulphate anhydrous, filtered and evaporated to dryness $(7.1 \mathrm{~g})$.

\section{FRACTIONATION AND ISOLATION}

The extract $(2.6 \mathrm{~g})$ was fractionated by column chromatography on silica gel (100 g, 70-230 mesh) (column $3 \times 100 \mathrm{~cm}$ ) eluting successively with hexane/ $\mathrm{CH}_{2} \mathrm{Cl}_{2}\left(4: 6-0: 1,5 \%\right.$ increment of $\left.\mathrm{CH}_{2} \mathrm{Cl}_{2}\right)$ then $\mathrm{CH}_{2} \mathrm{Cl}_{2}$ / $\operatorname{EtOAc}(9: 1-1: 1,10 \%$ increment of EtOAc) and a gradient of $\mathrm{CH}_{2} \mathrm{Cl}_{2} / \mathrm{EtOAc} / \mathrm{Me}_{2} \mathrm{CO}$ (10:9:1-2:7:1, 10\% and 1\% increment of EtOAc and $\mathrm{Me}_{2} \mathrm{CO}$, respectively, to furnished 10 fractions (F1 - F10). Fractions F3, F4 and F10 were subjected to bioautography agar overlay assay which showed RA2, RA3 and RA9 as the antimicrobial active alkaloids. Fraction F3 (50 mg) was rechromatographed by column chromatography (40 g) (column $2 \times 40 \mathrm{~cm}$ ) with hexane $/ \mathrm{CH}_{2} \mathrm{Cl}_{2}$ (4:6-2:8, $1 \%$ increment of $\mathrm{CH}_{2} \mathrm{Cl}_{2}$ then $1-2 \%$ of EtOAc) to give 3 fractions (F3-1 - F3-3). Fraction F3-3 (150 mg) was further purified by chromatotron (1 mm thickness) with $100 \%$ pet-ether then a gradient of pet-ether/ $\mathrm{CH}_{2} \mathrm{Cl}_{2}$ (99:1-8:2, 1\% increment of $\mathrm{CH}_{2} \mathrm{Cl}_{2}$ then $1 \%$ increment of EtOAc with subsequent $1 \%$ decrement of $\mathrm{CH}_{2} \mathrm{Cl}_{2}$. RA2 or arborinine (1) was eluted with pet-ether/ $\mathrm{CH}_{2} \mathrm{Cl}_{2} /$ EtOAc (80:6:14) (30 mg, 1.2\%). A total of 20 mg Fraction F4 was separated by chromatotron (1 mm thickness) with mixture of RA3 or skimmianine (2) (0.8 $\mathrm{mg}, 0.03 \%)$ was purified from fraction F4 $(20 \mathrm{mg})$ by using chromatotron ( $1 \mathrm{~mm}$ thickness) eluted with pet-ether/ $\mathrm{CH}_{2} \mathrm{Cl}_{2} / \mathrm{EtOAc}(80: 11: 9)$ at the flow rate of 2 to $3 \mathrm{~mL} / \mathrm{min}$. Fraction F10 (120 mg) was rechromatographed on silica gel $(15 \mathrm{~g})($ column $2 \times 20 \mathrm{~cm})$ eluting consecutively with pet-ether/ $\mathrm{CH}_{2} \mathrm{Cl}_{2}\left(1: 1-0: 1,10 \%\right.$ increment of $\left.\mathrm{CH}_{2} \mathrm{Cl}_{2}\right)$ and $\mathrm{CH}_{2} \mathrm{Cl}_{2} / \mathrm{MeOH}$ (99:1 and 98:2). RA9 or graveoline (3) was eluted with $\mathrm{CH}_{2} \mathrm{Cl}_{2} / \mathrm{MeOH}$ (98:2) (80 mg, 3.1\%).

\section{ANTIMICROBIAL ACTIVITY}

\section{TEST MICROORGANISMS}

Three bacterial strains of American Type Culture Collection (ATCC), namely Staphylococcus aureus ATCC 25923, Escherichia coli ATCC 25922 and Enterococcus faecalis ATCC 29212 were used in this study.

\section{INOCULA FOR ANTIMICROBIAL TESTS}

The inocula for antimicrobial testing were prepared according to Rahalison et al. (1991). The inoculum size of $18 \mathrm{~h}$ culture incubated at $37^{\circ} \mathrm{C}$ was adjusted by using 
UV spectrophotometer to an absorbance of 0.11 to 0.12 at $600 \mathrm{~nm}$.

\section{BIOAUTOGRAPHY AGAR OVERLAY ASSAY}

This assay was performed according to the bioautographic procedures (Rahalison et al. 1991) with a few modifications. All fractions were chromatographed on $4 \mathrm{~cm} \times 10 \mathrm{~cm}$ TLC commercial aluminium sheets Silica gel $60 \mathrm{~F}_{254}$ of layer thickness $0.2 \mathrm{~mm}$. The chromatogram was rapidly distributed with $5 \mathrm{~mL}$ of inoculated molten agar at $35^{\circ} \mathrm{C}$. After solidification of the agar, the TLC plates were kept in sterile petri dishes lined with moist filter papers and incubated at $37^{\circ} \mathrm{C}$ for $24 \mathrm{~h}$. The plates were sprayed with an aqueous solution of $0.5 \%$ 2-[4-iodo-phenyl]-3[4-nitrophenyl]-5-phenyl-tetrazolium chloride (INT) and reincubated for $4 \mathrm{~h}$. The active alkaloids were detected as the clear zones against a pink background of viable microbes. The reference chromatograms were visualized under UV lights and sprayed with Dragendorff's reagent.

\section{BROTH MICRODILUTION ASSAY}

The minimum inhibitory concentrations (MICs) of graveoline and selected antibiotics were determined in triplicate against the test microorganisms by broth microdilution assay following the Clinical and Laboratory Standards Institute (CLSI) 2006 method with some modifications. Stock solution of gaveoline was twofold serially diluted in 96 well microtiter plate to obtain concentrations ranging from 1.56 to $1000 \mu \mathrm{g} / \mathrm{mL}$. Standard antibiotics were prepared at a few ranges of concentrations from 0.48 to $500 \mu \mathrm{g} / \mathrm{mL}$ by two-fold serial dilution of two, five or ten times diluted stock solution of $1000 \mu \mathrm{g} / \mathrm{mL}$. The microbial inocula were diluted hundred times to an approximate concentration of $1 \times 10^{5}$ colony forming unit $(\mathrm{CFU}) / \mathrm{mL}$ with sterile broth. Each well contained a final volume of $200 \mu \mathrm{L}$ of $180 \mu \mathrm{L}$ of inoculated broth and 20 $\mu \mathrm{L}$ of tested solution. The assay was repeated with diluents to check their effects on bacterial growth. Wells with bacterial suspension and uninoculated broth are included as normal growth and sterility control, respectively. The plates were incubated for $18 \mathrm{~h}$ at $37^{\circ} \mathrm{C} .10 \mu \mathrm{L}$ of $0.25 \%$ (3-[4,5-dimethylthiazol-2-yl]-2,5-diphenyl-tetrazolium bromide (MTT) was added to each well subsequent to incubation for another $30 \mathrm{~min}$. A colour change from yellow to blue indicated the presence of viable bacteria. MIC was recorded as the lowest concentration with no colour changes. The minimum bactericidal concentration (MBC) was determined by streaking a loopful of mixture from each well with no colour changes onto agar and incubated at $37^{\circ} \mathrm{C}$ for $24 \mathrm{~h}$. MBC was recorded as the lowest concentration with no bacterial growth.

\section{CHECKERBOARD ASSAY}

The antimicrobial combination effects between graveoline and either erythromycin or vancomycin were studied following the CLSI 2006 guideline with some modifications. Two-fold serial dilutions of graveoline and antibiotic alone were performed in a volume of $20 \mu \mathrm{L}$ per well in the first column and row of a 96-well microtiter plate, respectively. For graveoline-antibiotic combination, $10 \mathrm{uL}$ of each concentration of a serially diluted antibiotic solution was put in each well of the same remaining row of the plate. Then, each well was added with $180 \mu \mathrm{L}$ of 100 fold diluted inoculum. After $60 \mathrm{~min}$ incubation at room temperature, $10 \mu \mathrm{L}$ of each concentration of a serially diluted graveoline solution was added in each well of the same column, so that each row contained a fixed amount of antibiotic while decreasing amounts of graveoline. All plates were incubated at $37^{\circ} \mathrm{C}$ for $18 \mathrm{~h}$ and the MIC values were confirmed by $0.25 \%$ MTT. The fractional inhibitory concentration (FIC) and the FIC indices (FICI) were calculated and interpreted following Orhan et al. (2005). The results were determined from the majority of three independent tests. The procedure was repeated for ciprofloxacin-antibiotic combination where ciprofloxacin

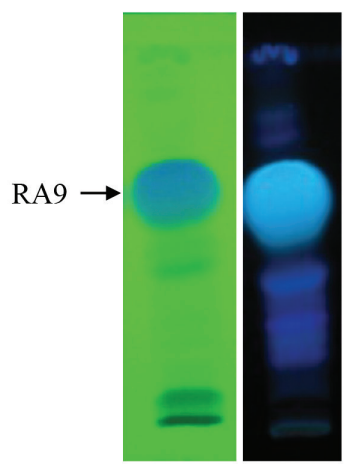

(a)

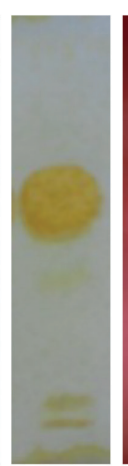

(c)

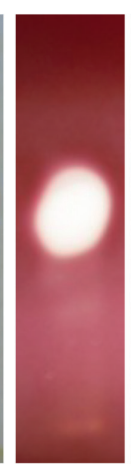

(d)

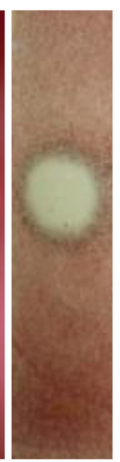

(e)

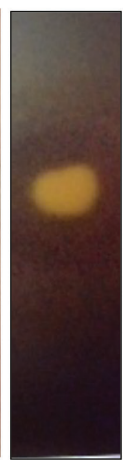

(f)

FIGURE 1. Antimicrobial bioautographic profile of fraction R10 of $R$. angustifolia leaves alkaloidal extract showing RA9 or graveoline as the active alkaloid of the fraction, (a) and (b) reference chromatograms viewed under $\mathrm{UV}_{254}$ and $\mathrm{UV}_{365}$ light, respectively, (c) reference chromatogram sprayed with Dragendorff's reagent (d), (e) \& (f) bioautograms against S. aureus ATCC 25923, E. faecalis ATCC 29212 and E. coli ATCC 25922, respectively. Chromatographic conditions: pre-coated aluminium silica gel $60 \mathrm{~F}_{254}$ of $0.2 \mathrm{~mm}$ thickness, solvent system, $\mathrm{CH}_{2} \mathrm{Cl}_{2}: \mathrm{MeOH}(9: 1)$ 
was used as the reference for quinolone antimicrobial agent.

\section{RESULTS AND DISCUSSION}

Antimicrobial bioautography-guided isolation of alkaloidal fractions of $R$. angustifolia leaves has led to the identification of a major active alkaloid identified as graveoline (3) together with arborinine (1) and the minor alkaloid, skimmianine (2) (Figures 1 \& 2). Graveoline possessed MIC values of $500 \mu \mathrm{g} / \mathrm{mL}$ against $E$. faecalis and $1000 \mu \mathrm{g} / \mathrm{mL}$ for $S$. aureus and E. coli (Table 1). The susceptibility values are within the range regarded for antimicrobial active phytochemicals (Monte et al. 2014). Antimicrobial active alkaloids may possess different mechanism of action than those of antibiotics which might potentiate the activity of the later when used in combination (Cushnie et al.2014). Therefore, combination of graveoline, a natural 4-quinolone alkaloid with either erythromycin, a macrolide or vancomycin, a glycopeptide was performed with the objective of achieving higher efficacy in their activity with desirable synergistic effect possible for preventing drug resistance in the future. The combination effects were compared to that of ciprofloxacin which is a synthetic quinolone antimicrobial agent.

Graveoline possesses a structural characteristic of quinolone antimicrobial agent by bearing completely aromatic 4-quinolone ring with specific substituents at C-1, C-5 and C-8 but lacking in a 4-pyridone ring with 3 -carboxyl group which is the essential pharmacophore for exerting significant antibacterial activity (Chung et al. 2015; Emami et al. 2005). Nevertheless, it could be presumed that graveoline might possesses a few characteristics mechanism of action of the quinolones although at weaker activity. The graveoline-antibiotic interactions against $S$. aureus, E. faecalis and E. coli were recorded as synergy, partial synergy, additive and indifference, respectively, based on their FICI values (Orhan et al. 2005) (Table 2). The MICs of both graveoline and antibiotics were substantially reduced although to a variable extent as compared to the values when tested alone against $S$. aureus and $E$. coli. $S$. aureus was the most susceptible microbe towards graveoline-antibiotic interactions.

Graveoline-erythromycin combination resulted in synergy effect with the FICI of 0.37 and reduced MIC by<smiles>COc1ccc2c(OC)c3ccoc3nc2c1OC</smiles>

1<smiles>COc1cc2c3c(c1OC)OC[O+]=C3c1ccccc1N2C</smiles>

2<smiles>Cn1c(-c2ccc3c(c2)OCO3)cc(=O)c2ccccc21</smiles>

3

FIGURE 2. Antimicrobial active alkaloids of Ruta angustifolia

6-folds and 4-folds for graveoline and erythromycin, respectively. Graveoline-vancomycin interaction produced partial synergy effect with FICI value of 0.5 . Erythromycin and vancomycin are clinically used antibiotics particularly against Gram-positive bacterial infections. Erythromycin disrupts protein synthesis by inhibiting peptide elongation on the ribosome (Gaynor \& Mankin 2003) whereas vancomycin is an inhibitor to cell wall peptidoglycan synthesis (Kang \& Park 2015). The combination effects could be attributed to the dual actions of both agents at different target sites of the bacterial cells. Indifference effect with 2-folds reduction to the MIC of erythromycin

TABLE 1. Quantitative antimicrobial activity of graveoline from R. angustifolia and selected antibiotic standards

\begin{tabular}{lcccccc}
\hline \multirow{2}{*}{ Test compound } & \multicolumn{6}{c}{ Antimicrobial Activity $(\mu \mathrm{g} / \mathrm{mL})$} \\
\cline { 2 - 7 } & \multicolumn{2}{c}{ S. aureus } & \multicolumn{2}{c}{ E. faecalis } & \multicolumn{2}{c}{ E.coli } \\
\cline { 2 - 7 } & MIC & MBC & MIC & MBC & MIC & MBC \\
\hline Graveoline & 1000 & $>1000$ & 500 & 1000 & 1000 & $>1000$ \\
Ciprofloxacin & 0.195 & 0.195 & 1.562 & 1.562 & 0.039 & 0.039 \\
Erythromycin & 1.098 & 1.098 & 0.78 & 0.78 & 50 & 50 \\
Vancomycin & 2.50 & 2.50 & 3.13 & 3.13 & 250 & 500 \\
\hline
\end{tabular}


TABLE 2. Antimicrobial combination effects between graveoline and either erythromycin or vancomycin against $S$. aureus ATCC 25923, E. faecalis ATCC 29212 and E. coli ATCC 25922 with comparison to that of ciprofloxacin

\begin{tabular}{|c|c|c|c|c|c|c|}
\hline Bacteria & Combination & $\begin{array}{l}\text { MIC alone } \\
(\mu \mathrm{g} / \mathrm{mL})\end{array}$ & $\begin{array}{l}\text { MIC in combination } \\
(\mu \mathrm{g} / \mathrm{mL})\end{array}$ & FIC & FICI & Combination effect \\
\hline \multirow{8}{*}{$\begin{array}{l}\text { S. aureus } \\
\text { ATCC } 25923\end{array}$} & Graveoline & 1000 & 125 & 0.12 & \multirow{2}{*}{0.37} & \multirow{2}{*}{ Synergy } \\
\hline & Erythromycin & 1.098 & 0.274 & 0.25 & & \\
\hline & Graveoline & 1000 & 250 & 0.25 & \multirow{2}{*}{0.50} & \multirow{2}{*}{ Partial synergy } \\
\hline & Vancomycin & 2.50 & 0.625 & 0.25 & & \\
\hline & Ciprofloxacin & 0.195 & 0.098 & 0.50 & \multirow{2}{*}{1.00} & \multirow{2}{*}{ Additive } \\
\hline & Erythromycin & 1.098 & 0.547 & 0.50 & & \\
\hline & Ciprofloxacin & 0.195 & 0.098 & 0.50 & \multirow{2}{*}{1.00} & \multirow{2}{*}{ Additive } \\
\hline & Vancomycin & 2.50 & 1.25 & 0.50 & & \\
\hline \multirow{8}{*}{$\begin{array}{l}\text { E.faecalis } \\
\text { ATCC } 29212\end{array}$} & Graveoline & 500 & 500 & 1.00 & \multirow{2}{*}{1.50} & \multirow{2}{*}{ Indifference } \\
\hline & Erythromycin & 0.781 & 0.39 & 0.50 & & \\
\hline & Graveoline & 500 & 500 & 1.00 & \multirow{2}{*}{2.00} & \multirow{2}{*}{ Indifference } \\
\hline & Vancomycin & 3.13 & 3.13 & 1.00 & & \\
\hline & Ciprofloxacin & 1.562 & 0.781 & 0.50 & \multirow{2}{*}{1.00} & \multirow{2}{*}{ Additive } \\
\hline & Erythromycin & 0.781 & 0.39 & 0.50 & & \\
\hline & Ciprofloxacin & 1.562 & 0.781 & 0.50 & \multirow{2}{*}{1.00} & \multirow{2}{*}{ Additive } \\
\hline & Vancomycin & 3.125 & 1.562 & 0.50 & & \\
\hline \multirow{8}{*}{$\begin{array}{l}\text { E. coli } \\
\text { ATCC } 25922\end{array}$} & Graveoline & 1000 & 250 & 0.25 & \multirow{2}{*}{0.75} & \multirow{2}{*}{ Partial synergy } \\
\hline & Erythromycin & 50 & 25 & 0.50 & & \\
\hline & Graveoline & 1000 & 250 & 0.25 & \multirow{2}{*}{0.75} & \multirow{2}{*}{ Partial synergy } \\
\hline & Vancomycin & 250 & 125 & 0.50 & & \\
\hline & Ciprofloxacin & 0.039 & 0.019 & 0.50 & \multirow{2}{*}{0.53} & \multirow{2}{*}{ Partial synergy } \\
\hline & Erythromycin & 50 & 1.562 & 0.03 & & \\
\hline & Ciprofloxacin & 0.039 & 0.002 & 0.05 & \multirow{2}{*}{0.18} & \multirow{2}{*}{ Synergy } \\
\hline & Vancomycin & 250 & 7.813 & 0.13 & & \\
\hline
\end{tabular}

FICI $<0.5$, synergy; $0.5-0.75$, partial synergy; $>0.75$ to 1.0 , additive effect; $>1.0$ to 4.0 indifference and $>4$, antagonism (Orhan et al. 2005$)$

was produced in graveoline-antibiotic combinations against $E$. faecalis. The results showed that graveolineantibiotic actions occurred at a different susceptibility degree against different bacteria.

Both graveoline-antibiotic combinations against $E$. coli indicated a partial synergy with 4 -folds reduction in the MIC of graveoline and 2-folds reduction of both erythromycin and vancomycin. Although vancomycin is considered inactive against Gram-negative bacteria due to variety of mechanisms involve in its cell wall synthesis and factors that affect membrane permeability (Kang $\&$ Park 2015), the resulted partial synergy effect for its combinations with graveoline suggested for effective combination for glycopeptide against Gram-negative $E$. coli. The partial synergy could be attributed to the actions of both agents at different targets consisting of disruption of cell wall synthesis by vancomycin which increase membrane permeability of graveoline to its target sites while inhibition of protein synthesis by erythromycin enhanced graveoline activity.

Combinations involving ciprofloxacin have resulted in additive interaction by which in every combination, both combined antibiotics exhibited 2-folds of MIC reduction and thus gave the FIC index of 1.00 against both Gram-positive S. aureus and E. faecalis. The result is in agreement to the previous finding on the influence of non-quinolone antimicrobial agents such as macrolides (Gradelski et al. 2001) and glycopeptides (Noviello et al. 2001) which demonstrated additive interactions with ciprofloxacin by all dual drug combinations. In E. coli, ciprofloxacin-erythromycin combination achieved partial synergy by 32-folds reduction in the MIC of erythromycin. A synergistic interaction was achieved for ciprofloxacin and vancomycin combination with 16 -folds reduction of the MIC of the former and enhancement of the antimicrobial activity of the later by 32 -folds. Ciprofloxacin is a broad spectrum antibiotic which is more susceptible to Gramnegative bacteria than Gram-positive bacteria. It rapidly inhibits bacterial growth by primarily interfering with the DNA synthesis in combination with its efficient membrane permeability (Cramariuc et al. 2012) which resulted to a noticeable reduction of erythromycin and vancomycin. The findings showed that graveoline was a synergistic enhancer to erythromycin which is superior combination 
agent than ciprofloxacin against $S$. aureus whereas it was inferior agent than ciprofloxacin against $E$. coli.

The identification details of the isolated antimicrobial alkaloids are shown as follows:

Compound 1 2,3-dimethoxy-1-hydroxy-10-methylacridone [Arborinine]; $\mathrm{C}_{16} \mathrm{H}_{15} \mathrm{NO}_{4}$; MW: $285 \mathrm{~g} / \mathrm{mol}$; bright yellow fine needle-shaped crystals; MP: $175-176^{\circ} \mathrm{C}$, Rf: 0.67 $\left(\mathrm{CHCl}_{3}\right)$; IR $\left(\mathrm{CHCl}_{3}\right) \mathrm{cm}^{-1}: 1641,1591,1556,1463,1322$, 1251, 1188, 1139, 1106, 1058, 989, 918, 849, 784, 753; $\mathrm{UV} / \mathrm{Vis} \lambda_{\max }(\mathrm{MeOH}) \mathrm{nm}(\log \varepsilon): 230$ (3.79), 274 (4.24), 399 (3.41); ${ }^{1} \mathrm{H}$ NMR (500 MHz, $\left.\mathrm{CDCl}_{3}\right): 14.73$ (1H, s, $1-\mathrm{OH}), 8.39(1 \mathrm{H}, \mathrm{dd}, J=1.7$ and $8.2 \mathrm{~Hz}, \mathrm{H}-8), 7.70(1 \mathrm{H}$, $\mathrm{m}, \mathrm{H}-6), 7.47(1 \mathrm{H}, \mathrm{d}, J=8.6 \mathrm{~Hz}, \mathrm{H}-5), 7.26(1 \mathrm{H}, \mathrm{t}, J=$ $7.4 \mathrm{~Hz}, \mathrm{H}-7), 6.24$ (1H, s, H-4), 4.00 (3H, s, 2-OMe), 3.92 (3H, s, 3-OMe), 3.82 (3H, s, N-Me); ${ }^{13} \mathrm{C}$ NMR (100 MHz, $\mathrm{CDCl}_{3}$ ) ঠ: 180.6 (C-9), 159.2 (C-3) 155.9 (C-1), 141.8 (C-10a), 140.3 (C-4a), 133.9 (C-6), 130.0 (C-2), 126.4 (C8), 121.4 (C-7), 120.50 (C-8a), 114.6 (C-5), 105.6 (C-9a), $86.7(\mathrm{C}-4), 60.8\left(2-\mathrm{OCH}_{3}\right), 55.9\left(3-\mathrm{OCH}_{3}\right), 34.0\left(\mathrm{~N}-\mathrm{CH}_{3}\right)$; MS (EI, $70 \mathrm{eV}): m / z(\%)=285\left[\mathrm{M}+\mathrm{H}^{+}\right](52), 270(100)$, 256 (15), 242 (85), 227 (5), 212 (12), 199 (59), 171 (12), 143 (9), 115 (10).

Compound 2 4,7,8-trimethoxyfuro[2,3-b]quinoline [Skimmianine]; Formula: $\mathrm{C}_{14} \mathrm{H}_{13} \mathrm{NO}_{4}$ MW: $259 \mathrm{~g} / \mathrm{mol}$, colorless rhombohedral prisms; MP: $175-176^{\circ} \mathrm{C}$; Rf: 0.52 $\left(\mathrm{CHCl}_{3}\right)$; IR $\left(\mathrm{CHCl}_{3}\right) \mathrm{cm}^{-1}: 1616,1575,1389,1364,1266$, 1088, 950; UV/Vis $\lambda_{\text {max }}(\mathrm{MeOH}) \mathrm{nm}(\log \varepsilon): 250$ (4.30), 332 (3.39); ${ }^{1} \mathrm{H}$ NMR $\left(500 \mathrm{MHz}, \mathrm{CDCl}_{3}\right): 8.03$ (1 H, d, J = $9.5 \mathrm{~Hz}, \mathrm{H}-5), 7.61(1 \mathrm{H}, \mathrm{d}, \mathrm{J}=2.5 \mathrm{~Hz}, \mathrm{H}-2), 7.25(1 \mathrm{H}, \mathrm{d}, \mathrm{J}$ $=9.5 \mathrm{~Hz}, \mathrm{H}-6), 7.06(1 \mathrm{H}, \mathrm{d}, \mathrm{J}=2.5 \mathrm{~Hz}, \mathrm{H}-3), 4.45(3 \mathrm{H}, \mathrm{s}$, 4-OMe), 4.14 (3 H, s, 8-OMe), 4.05 (3 H, s, 7-OMe); ${ }^{13} \mathrm{C}$ NMR (100 MHz, CDCl $)$ ) $\delta: 164.6$ (C-9a), 157.5 (C-4), 152.4 (C-8a), 143.1 (C-2), 142.1 (C-7), 141.2 (C-8), 118.3 (C-5), 115.1 (C-3a), 112.1 (C-6), 104.7 (C-3), 102.1 (C-4a), 61.7 $\left(8-\mathrm{OCH}_{3}\right), 59.1\left(4-\mathrm{OCH}_{3}\right), 56.8\left(7-\mathrm{OCH}_{3}\right) ; \mathrm{MS}(\mathrm{EI}, 70 \mathrm{eV})$ : $\mathrm{m} / \mathrm{z}(\%)=259\left[\mathrm{M}+\mathrm{H}^{+}\right](64), 230(5), 216(4), 172$ (2).

Compound 3 1-methyl-2-[3',4'-methylenedioxyphenyl]-4quinolone [Graveoline]; Formula: $\mathrm{C}_{18} \mathrm{H}_{17} \mathrm{O}_{3} \mathrm{~N}$; MW: $279 \mathrm{~g} /$ mol; white amorphous powder; MP: $185-186^{\circ} \mathrm{C}$; Rf: 0.58 $\left(\mathrm{CHCl}_{3}: \mathrm{MeOH}, 9: 1\right)$; IR $\left(\mathrm{CHCl}_{3}\right) \mathrm{cm}^{-1}: 1621,1597,1563$, 1486, 1446, 1250, 1036, 827, 760; UV/Vis $\lambda_{\max }(\mathrm{MeOH}) \mathrm{nm}$ (log $\varepsilon): 243$ (4.18), 324 (3.89), 336 (3.90); ${ }^{1} \mathrm{H}$ NMR (500 $\left.\mathrm{MHz}, \mathrm{CDCl}_{3}\right): 8.50(1 \mathrm{H}, \mathrm{dd}, J=1.5$ and $8.0 \mathrm{~Hz}, \mathrm{H}-5)$, $7.74(1 \mathrm{H}, \mathrm{t}, J=8.5 \mathrm{~Hz}, \mathrm{H}-7), 7.57(1 \mathrm{H}, \mathrm{d}, J=8.5 \mathrm{~Hz}$, $\mathrm{H}-8), 7.40(1 \mathrm{H}, \mathrm{t}, J=8.0 \mathrm{~Hz}, \mathrm{H}-6), 6.88(1 \mathrm{H}, \mathrm{d}, J=1.5 \mathrm{~Hz}$, H-2'), $6.91\left(1 \mathrm{H}, \mathrm{s}, \mathrm{H}-3^{\prime}\right), 6.88\left(1 \mathrm{H}, \mathrm{d}, J=1.5, \mathrm{H}-6^{\prime}\right), 6.37$ (1H, s, H-3), 6.09 (2H, s, $\left.\mathrm{OCH}_{2} \mathrm{O}\right), 3.70$ (3H, s, N-Me); ${ }^{13} \mathrm{C}$ NMR (100 MHz, $\mathrm{CDCl}_{3}$ ) $\delta: 177.3$ (C-4), 154.7 (C-2), 148.8 (C-4'), 147.9 (C-5'), 141.9 (C-8a), 132.5 (C-2'), $129.3\left(\mathrm{C}-1^{\prime}\right), 126.7$ (C-4a), 126.6 (C-7), 123.9 (C-6), 122.8 (C-5), 116.1 (C-8), 112.5 (C-3), 109.0 (C-3'), 108.7 (C-6'), $101.8\left(\mathrm{OCH}_{2} \mathrm{O}\right), 37.5\left(\mathrm{~N}-\mathrm{CH}_{3}\right)$; $\mathrm{MS}(\mathrm{EI}, 70 \mathrm{eV}): \mathrm{m} / \mathrm{z}(\%)=$ $279\left[\mathrm{M}+\mathrm{H}^{+}\right](60), 251$ (100), 192 (17).

\section{CONCLUSION}

The synergistic action of the combination between graveoline, a natural quinolone alkaloid and erythromycin, a macrolide or vancomycin, a glycopeptide possesses a potential clinical significance as an alternative antimicrobial combination agent to be further researched for future benefit in overcoming or at least delaying the emergence of resistance in bacteria particularly against $S$. aureus .

\section{ACKNOWLEDGEMENTS}

A special gratitude is acknowledged to the Ministry of Higher Education Malaysia (MOHE) for funding the research through Fundamental Research Grant Scheme (FRGS0207-60) and International Islamic University Malaysia for the publication support (RIGS16-123-0287).

\section{REFERENCES}

Abreu,A.C., McBain,A.J. \& Simões, M. 2012.Plants as sources of new antimicrobials and resistance-modifying agents. Natural Product Reports 29(9): 1007-1021.

Chung, P.Y., Bian, Z.X., Pun, H.Y., Chan, D., Chan, A.S.C., Chui, C.H., Tang, J.C.O. \& Lam, K.H. 2015. Recent advances in research of natural and synthetic bioactive quinolines. Future Medicinal Chemistry 7(7): 947-967.

CLSI. 2006. Methods for Dilution Antimicrobial Susceptibility Tests for Bacteria that Grow Aerobically, Approved Standard, 7th edition, document M7-A7 [ISBN 1-56238-587-9]. Wayne, Clinical and Laboratory Standards Institute.

Cramariuc, O., Rog, T., Javanainen, M., Monticelli, L., Polishchuk, A.V. \& Vattulainen, I. 2012. Mechanism of translocation of fluoroquinolones across lipid membranes. Biochimica et Biophysica Acta 1818: 2563-2572.

Cushnie, T.P., Cushnie, B. \& Lamb, A.J. 2014. Alkaloids: An overview of their antibacterial, antibiotic-enhancing and antivirulence activities. Int. J. Antimicrob. Agents 44(5): 377-386.

da Silva, M.F.G.F., Fernandes, J.B., Forim, M.R., Vieira, P.C. \& de Sa, I.G.C. 2013. Alkaloids derived from anthranilic acid: Quinoline, acridone, and quinazoline in Natural Product, edited by Ramawat, K.G. \& Merillon, J.M. Berlin Heidelberg: Springer-Verlag. pp: 715-858.

El Sayed, K., Al-Said, M.S., El-Feraly, F.S. \& Ross, S.A. 2003. New quinoline alkaloid from Ruta chalepensis. Journal of Natural Product 63: 995-997.

Emami, S., Shafiee, A. \& Foroumadi, A. 2005. Quinolones: Recent structural and clinical development. Iranian Journal of Pharmaceutical Research 3: 123-136.

Gaynor, M. \& Mankin, A.S. 2003. Macrolide antibiotics: Binding site, mechanism of action, resistance. Current Topics in Medicinal Chemistry 3: 949-961.

Gradelski, E., Kolek, B., Bonner, D.P., Valera, L., Minassian, B. \& Fung-Tomc, J. 2001. Activity of gatifloxacin and ciprofloxacin in combination with other antimicrobial agents. International Journal Antimicrobial Agents 17: 103-107.

Hemaiswarya, S. \& Doble, M. 2010. Synergistic interaction of phenylpropanoids with antibiotics against bacteria. Journal of Medical Microbiology 59: 1469-1476.

Kang, H.K. \& Park, Y. 2015. Glycopeptide antibiotics: Structure and mechanisms of action. Journal of Bacteriology and Virology 45(2): 67-78. 
Koh, H.L., Chua, T.K. \& Tan, C.H. 2009. A Guide to Medicinal Plants: An Illustrated, Scientific and Medicinal Approach. Singapore: World Scientific. p. 135.

Kyaw, B.M., Shuchi, A.S. \& Lim, C.S. 2012. Bactericidal antibiotic-phytochemical combinations against methicillin resistant Staphylococcus aureus. Brazilian Journal of Microbiology 43(3): 938-945.

Linda, E., Maya, A.F., Shannon, B.F., Jan, W., Brian, K.C., Mike, T., Eric, D.B. \& Gerard, D.W. 2011. Combinations of antibiotic and non-antibiotic drugs enhance antimicrobial efficacy. Nature Chemical Biology 7: 348-350.

Monte, J., Abreu, A.C., Borges, A., Simões, L.C. \& Simões, M. 2014. Antimicrobial activity of selected phytochemicals against Escherichia coli and Staphylococcus aureus and their biofilms. Pathogen 3: 473-498.

Noviello, S., Ianniello, F. \& Esposito, S. 2001. In vitro activity of LY333328 (oritavancin) against Gram-positive aerobic cocci and synergy with ciprofloxacin against enterococci. $J$. Antimicrobial Chemotherapy 48: 283-286.

Orhan, G., Bayram, A., Zer, Y. \& Balci, I. 2005. Synergy tests by E test and checkerboard methods of antimicrobial combinations against Brucella melitensis. Journal of Clinical Microbiology 43(1): 140-143.

Rahalison, L., Hamburger, M. \& Hostettman, K.A. 1991. Bioautographic agar overlay method for the detection of antifungal compounds from higher plants. Phytochemical Analysis 2: 199-203.

Raj, M.P., Arora, L. \& Kumar, N.A. 2013. Phytochemicals extraction of alkaloids from Ruta graveolens (Snake repellent plant) and evaluation of its antibacterial and antifungal activity. International Journal of Biological Research 1(1): $1-10$.
Shamsul, K., Tajuddin, A.M. \& Mazina, M.Y. 2003. Tumbuhan Ubatan Tradisional Malaysia. Serdang: Institut Biosains Universiti Putra Malaysia. p. 87.

Tamma, P.D., Cosgrove, C.E. \& Finch, R. 2012 Combination therapy for treatment of infections with Gram-negative bacteria. Clinical Microbiology Review 25(3): 450-470.

World Health Organization (WHO). 2017. Antimicrobial Resistance. Fact Sheet No. 194. http://www.who.int/ mediacentre/factsheets/fs194/en/. Accessed on January 7, 2018.

Laina Zarisa Mohd Kamal, Norazian Mohd Hassan* \& Nurhaya Md Taib

Department of Pharmaceutical Chemistry

Kulliyyah of Pharmacy

International Islamic University Malaysia

25200 Kuantan, Pahang Darul Makmur

Malaysia

May Khin Soe

Department of Basic Medical Sciences

Kulliyyah of Pharmacy

International Islamic University Malaysia

25200 Kuantan, Pahang Darul Makmur

Malaysia

*Corresponding author; email: norazianmh@iium.edu.my

Received: 9 April 2017

Accepted: 7 June 2018 